\title{
Corporate Leadership, Multilevel Enforcement and Biodiversity Regulation
}

\author{
João Paulo Cândia Veiga $a^{*}$, Fausto Makishi ${ }^{*}$, Murilo Alves Zacareli ${ }^{*}$, Thiago Augusto \\ Hiromitsu Terada $\mathrm{d}^{*}$
}

\author{
aUniversity of São Paulo \\ b University of São Paulo \\ c University of São Paulo \\ d Beraca Institute \\ *Correspondingauthor'semailaddress: candia@usp.br
}

\section{A R T I C LE IN F O}

Received: 30-04-2016

Accepted: 24-05-2016

Available online: 10-07-2016

Keywords:

Biodiversity; Corporatism;

Governance; Regulation;

Transnational.

JEL Classification: Q23; Q43; Q53; Q56.

\begin{abstract}
A B S T R A C T
Globalization incentives the rise of non-state actors in unprecedented ways along with the creation of transnational arenas which are neither international (intergovernmental) nor national (domestic), but transborder political processes where firms, Non-Governmental Organizations (NGOs), states and social communities set up rules and provide governance mechanisms to enforce those at local level. The article is anchored in the idea that public-private governance matters where the primary driver is the market incentive. We test the hypotheses that public-private cooperation at local level is based on shared knowledge and expertise among firms, civil society and state authority dealing with a natural resource which comes from the Brazilian biodiversity. The central argument of this article is that the construction of a transnational arena to discuss issues such as sustainability, environment and social welfare determines the formation of a complex institutional environment, enforcement mechanisms and compliance which are heterogeneously dispersed. This paper develops a case study based on the leadership of Beraca in providing local governance for natural inputs.NGOs and companies have developed the ability to act as enforcers as they interpret the public international/national regulation and develop an expertise through 'best practices' that are applied to enforce biodiversity regulation at the local level through a multilevel system that operates transnationally.
\end{abstract}

This is an open access article under the terms of the Creative Commons Attribution License 4.0, which allows use, distribution and reproduction in any medium, provided the original work is properly cited.

\subsection{Introduction}

Globalization incentives the rise of non-state actors in unprecedented ways. The Private sector and NGOs, each one on their own, have produced cooperation on new issues of International Relations overcoming the states and formal International Organizations (IOs) as agents. We have witnessed the creation of transnational arenas which are neither international (intergovernmental) nor national (domestic). Transnational arenas are transborder political processes where firms, NGOs, states and social communities set up rules and provide governance to enforce them at local level. The transnational arena is a network of functional capabilities which come from different levels under the leadership of the private sector. Monitoring and the provision of information are key functional skills of this institutional design. 
In spite of the fact that states tend to be absent from transnational arenas, they operate in the 'shadows' (Börzel and Risse, 2010) because in the last resort they are the providers of the ultimate regulation. In the case of multinationals it is true they have gaineda tremendous power in operations everywhere. At the same time, globalization means a risky reputational environment mainly for manufacturers of consumer goods. For this reason, cooperation with NGOs is a core business activity because the legitimacy of the institutional arrangement at local level which comes from the transnational arena depends on auditing performance, monitoring, provision of information and transparency. Multinationals and their supply chains might have their activities verified by third parties and eventually be certified or labeled. The transnational arena also provides collective action at local level. Social movements, local communities in form of associations and cooperatives inputs the vertical flow through market incentives.

The result has been an apparatus of information flow and functional expertise from different actors, all connected in a network that overlaps states at the local level, social movements, NGOs and multinational firms in a multilevel governance system that aims to institutionalize public and private regulation. Diffuse 'authoritative' (Cutler, 2003) mechanisms enforce the rules based on corporate 'best practices', NGO's principles and normative demands from social actors.

The article is anchored in the idea that local public-private governance matters, as embedded in the domestic networks (private sector, NGOs and local authorities) where the primary driver is the market incentive. We test the hypotheses of public-private cooperation at local level based on shared knowledge and expertise among firms, civil society and state authority dealing with a natural resource which comes from the Brazilian biodiversity. The verified empirical outcome provides environmental protection and social welfare in rural communities located at the Amazon rainforest.

The fusion of national and international arenas was framed in different ways. Keohane and Ostrom suggested a convergence between analytical orientations of work on local Common-Pool Resources and environmental international regimes matched by the "fact that in various domains people seek to create rules to enable them to cooperate." (Keohane and Ostrom, 1995, p. 2). Cooperation at local level is the driver where the institutional arrangement must be build up. This approach must be 'merged' with International Relations theory of regimes where enforcement is top-down and based on state's sovereignty. At the same time, international regimes theory has never properly explained why and how the environmental regulation could be enforced (Young, 1999).

Enforcement is a wide concept discussed by the literature of Law, Political Science and International Relations that was conceived among states and IOs. Originally, enforcement is mainly applied to rules that are binding among the actors that agree to comply with them. However, what happens if enforcement is carried out by nonstate actors such as NGOs and companies? States and IOs have not been able to design and implement mechanisms to ensure that principles, rules and norms of treaties and conventions (international regimes) are fully enforced (Young, 1999). Thus, the traditional actors delegate the task to the non-state actors. These are the truly enforcers of global governance regimes, especially when it comes to environmental issues, such as biodiversity regulation (Katsikas, 2010, Bernstein, 2011, Young, 2011).

The central argument of this article is that the construction of a transnational arena to discuss issues such as sustainability, environment and social welfare determines the formation of a complex institutional environment, enforcement mechanisms and compliance which are heterogeneously dispersed. That is, while there is a movement to build cooperation and coordination relationships in a multilevel and polycentric context, incentives and instruments responsible for proper operation of the rules that form the institutions are not equally distributed, in particular with regard to the division of labor (specialization) as a transnational phenomenon.

The hypothesis is that multinational companies operating in international markets would be under strong pressure to develop social impact actions and environmental preservation in developing countries. Providers of these same companies would have less incentives to engage in these same practices. The absence or neglect of the state at the local arena and the greater distance from the conscious consumer market make the private sector responsible for the creation of incentives which will redesign complex governance structures to deal with this new scenario.

To illustrate this discussion, we reckon the contribution of the Nobel Prize, Douglas North that institutions are important and susceptible to analysis in order to establish a relationship between sustainable development (local and global) and the "rules of the game" set in a transnational arena. The lenses of the New Institutional Economics (NIE) for Matthews (1986), North (1991) and Williamson (1996; 2000) analyzes the development of 
a transnational agenda for dealing with the environmental issue that unfolds in new forms of systematic coordination (institutional arrangements) in the supply chains of the Brazilian biodiversity.

This paper develops a case study based on the leadership of Beraca in providing local governance for natural inputs. Section 2 exposes the theoretical background that supports the research object of this article. Section 3 explores the case of Beraca's biodiversity supply chain management. Section 4 addresses the political process involving transnational arenas and non-state actors. Section 5 analyzes Beraca's leadership through the lenses of Stakeholder Theory. Section 6 illustrates the discussions regarding the national public regulation for biodiversity and the relation to market incentives. The conclusion presented in section 7 summarizes the main findings and concludes with the analysis of the arenas and the authoritative mechanisms involved in the case of biodiversity.

Explanations for transnational arenas

NGOs and companies have the ability to act as enforcers as they develop an expertise through 'best practices' that are applied at the local level at the same time that they are connected to a wider transnational context that bridges the international, the national and the local arenas. In this context, Cashore (2002)has introduced a terminology to describe this process, namely the NSMDs. The Non-State Market Driven governance systems are influenced by market incentives and enforcement mechanisms provided by NGOs and companies.

Another explanation for transnational arenas comes from the authors of 'private authority'. The rise of private authority highlights market and social forces shaping the political process of convergence and expectations (Hall and Biersteker, 2002,Cutler, 2003,Büthe, 2010,Green, 2014). The term 'authoritative' is used to design a diffuse and hybrid authority, informally recognized by public and private actors in the process of scaling down or up (Hall and Biersteker, 2002). The recognition of rules by different actors in multilevel governance depends on this 'authoritative' mechanism. It is a way of NGOs to appropriate the intergovernmental multilateral public regulation and then it scales down to firms that enforce the rules at the national level under the state regulation. The local is the operational level where firms' 'best practices' and codes of conduct are implemented with cooperatives and producer's association.

A different set of explanations come from orquestration and transnational governance (Pattberg, 2007,Link and Link, 2009,Held and Hale, 2011,Green, 2014,Büthe and Mattli, 2011,Abbott and Snidal, 2010). Embedded in the international relations theories of cooperation, the approaches argue that the public-private partnerships are the best solutions to increase legitimacy, to provide expertise and to keep the state not as the traditional authority, but a supplier of public good through regulation and provision of information. This is a major positive scenario where public-private partnerships fill the gap of intergovernmental agendas and/or states and international organizations (IOs) delegate competencies to private/hybrid actors (Büthe and Mattli, 2011).

It doesn't means the state is fading away or implies its obsolescence or retreat. Abbott and Snidal (2010) and Büthe and Mattli (2011)preserve some core assumptions of international relations approaches: 1) the 'focal point' authority of the state (specific body or agency) in the contest of competition; and 2) the legitimacy of the State as a final resort (and IOs as agents). States and IOs must have some degree of recognized authority in orchestration and the capacity to coordinate non-state actors (NGOs and firms). The authors consider that there is some hierarchy between the public and the private spheres, e.g. traditional top-down command, as well as enforcement mechanisms.

Another perspective mixes institutional and sociological economics. The complexity of governance at local level needs different explanations. A bottom-up approach is based on Sociological Economics (Cashore 2002,Bartley, 2007,Raynolds, 2009,Abramovay et al., 2010) and Institutional Economics approaches (Coase, 1937,Keohane, 1984,North 1990). A more verticalized and inclusive approach at local-global level is necessary in order to detect latent 'conflicts of interests', and the 'learning process' among stakeholders (Cashore 2002). Institutional Economics and the seminal definition of North (1990) are the starting points: institutions are 'rules of the games' and the source of incentives "in human exchange, whether political, social or economic" (North 1990, p. 3 ). The idea of market failures is added as the asymmetry of information and transaction costs to explain publicprivate cooperation among local stakeholders. Monitoring and enforcing social and environmental standards at local level can be costly and will demand strict functional capabilities which can overlap the traditional local authority of state. The concept of 'governance structures' and transaction costs from Economics is used to explain the choices of the collective action at local level.

It is argued that the co-governance of public and private cooperation at local level can be at the same time: 1) 'voluntary' enforcement of standards and regulation from intergovernmental and multilateral decision-making 
in the form of Conventions and Protocols based on the United Nations system; 2) providers of technical expertise set up through 'know how' are jointly developed with local stakeholders (rural communities, NGOs as monitors and standard-setters, private sector and public authorities); and 3) providers of legitimacy to respond to global civil society demands (eventually through certification and labeling schemes from labor, environmental and organic standards) (Auld, 2014).

\subsection{The case of Beraca's biodiversity supply chain management}

Beraca is a Brazilian company that operates in the international market offering technology and services for different industries given that its main focus is the cosmetics and pharmaceutical industries. It acts in the 'business to business' market as the primary processing industry. The company, founded in 1956, initially operated in the chlorine market (chemical industry), but it was with the business of biodiversity products that it received worldwide recognition. Currently, it develops business in Brazil and in more than 40 countries. There are also international subsidiaries located in Paris and New Jersey.

Interestingly, the inputs sold by Beraca are gaining important highlight in the international market, largely because of the functional properties attributed to these natural substances that have a strong appeal to consumers of the cosmetics. In other words, these are high added value inputs or high aggregative capacityvalue.

The acting in the Amazon was consolidated in 2001 with the acquisition of Brazmazon. The company's strategy lies in the combination of coordination of certified natural food chains originated in an extensive network that includes over 2000 families, mostly located at the state of Pará. The sustainable use of these resources goes by the company's policy to incorporate the traditional knowledge of local communities to the business operation and to disseminate them in the form of management and knowledge technologies.

There is a very strong relationship between the business trajectory of its founder and Beraca's core business which is seen as 'path dependence'. During the first contact with the families who depended on the collection of fruits and seeds and fishing, the entrepreneur envisioned the possibility of making highly rudimentary processes into profitable and responsible activities, both for the local socioeconomic development and the preservation of the environment. Some factors stood out in the reality found in the communities: low prices and constant contract breaches due to the action of dealers, unsustainable practices for forest management such as forest fires and the exploitation of child labor, among many other irregularities. Since its foundation, Beraca's conduct of has been to offer an alternative to that reality found in the Amazon. This fact reflected in the construction of its close relationship with the supplier communities, given the value and the preservation of the forest.

At the other side, Beraca deals with consolidated worldwide consolidated companies known for their operational excellence, quality, regularity and innovation. The challenge for Beraca is to develop differentiated coordination mechanisms to align its extensive network of suppliers and the international market. It is a company of raw materials and natural inputs focusing on Brazil's biodiversity that works with a concept of sustainability oriented social investment and long-term regional development. For this, the company set up a network of stakeholders comprised of universities, NGOs, governments at various levels and certification bodies.

The origin of Beraca's competitive advantages could be associated with the combination of two key factors: effective coordination of supply chains and access to restricted and high market value resources. The long lasting relationships built between Beraca and its suppliers guarantee the company's performance in the international market of supplies for the cosmetics industry. In this sense, it is possible to say that Beraca does sell inputs, but supply chains.

Beraca's business activities follow three basic criteria, namely: 1) soil and biodiversity conservation, 2) working conditions and 3) energy efficiency and water resources management.

The soil conservation and biodiversity standards from the Business and Biodiversity platform developed in Germany in 2008bring together three dimensions: people (valuing the traditional local knowledge), natural resources (including sustainable management practices certified by the Forest Stewardship Council - FSC)and organic products (Ecocert certified). These principles and criteria were incorporated into the company's operation in the Amazon in a program called 'Valuing Biodiversity', a social and environmental management system that establishes procedures through indicators for the purchase of all forest products.

The working conditions follow the domestic and the international regulations and are applied not only in processing plants, but also along the chain, including suppliers and outsourced companies. Similarly, the concern 
with energy efficiency and water resources management tends to reflect in the form of corporate codes of conduct to the other participants in Beraca's chain.

Thus, Beraca's corporate management is a regulatory driver developed in the international and in the national to the local level. Examples of the initiatives incorporated by the company in the business activities are shown in table 1.

\section{Table 1: Beraca's Commitments}

United Nations Global Compact

Fórum Amazônia Sustentável

Na Mão Certa

Caring for Climate

Member of the Union For Ethical BioTrade (UEBT)
10 principles internalized by the company's management on Human Rights, Environment, Labor and Corruption Voluntary signatory of the 'Letter of Commitment' Childhood Brazil's initiative to combat the exploitation of children and adolescents in the country's highways

Commitment of business leaders for solutions to climate change with actions to the efficient use of energy to reduce $\mathrm{CO} 2$ emissions

Promotes the 'fair trade' of ingredients derived from the biodiversity

The relationship between the international institutional environment and the performance of Beraca locally is part of the problem of transnational arenas that are the target of this article. The institutional architecture in which the rules of the game that were internationally defined unfolds at the local level through corporate codes of conduct and has inspired and illuminated the empirical arguments presented in this article.

\subsection{Transnational arenas, non-state actors and the political process}

This section describes the functional linkage of different levels in order to disclosure the transnational arena on biodiversity (table 2). The intergovernmental multilateral sphere of International Relations kicks-off the process with the Convention on Biological Diversity and the Cartagena and Nagoya Protocols. Once rules on biodiversity protection and access and benefit sharing (ABS) are set up, states, firms and NGOs are pushed to find new dynamics to shape markets for social purposes and foster development in a transnational arena.

Inside the transnational arena, states enforce the rules at the national level, firms connect suppliers and customers everywhere and NGOs provide normative demands. When the transborder movements scale down to the local level, firms connect the global with the local building up the institutional arrangement and fostering the learning process from different expertise of different actors as shown in table 2.

\begin{tabular}{|c|c|c|c|c|}
\hline & Players & Incentives & Relationships & Information \\
\hline $\begin{array}{l}\text { International } \\
\text { Public } \\
\text { Actors }\end{array}$ & $\begin{array}{l}\text { United Nations } \\
\text { (CDB and Cartagena } \\
\text { and Nagoya } \\
\text { Protocols) }\end{array}$ & $\begin{array}{l}\text { Aggregated } \\
\text { information }\end{array}$ & Enforcement & $\begin{array}{l}\text { Information } \text { on } \begin{array}{l}\text { the } \\
\text { sustainable use of natural } \\
\text { resources }\end{array} \\
\end{array}$ \\
\hline $\begin{array}{l}\text { National } \\
\text { Public Actors }\end{array}$ & $\begin{array}{l}\text { CGEN (regulatory } \\
\text { authority) for the } \\
\text { Ministry for } \\
\text { Environment }\end{array}$ & $\begin{array}{l}\text { Compliance, } \\
\text { Enforcement and } \\
\text { Sanctioning }\end{array}$ & $\begin{array}{l}\text { Enforcement, } \\
\text { R\&D projects with firms }\end{array}$ & $\begin{array}{l}\text { Information on the projects } \\
\text { implementation }\end{array}$ \\
\hline $\begin{array}{l}\text { Local } \\
\text { Public } \\
\text { Actors }\end{array}$ & $\begin{array}{l}\text { Prefecture } \\
\text { Councils } \\
\text { Legislative and } \\
\text { Administrative } \\
\text { Bodies }\end{array}$ & $\begin{array}{l}\text { Improve welfare, } \\
\text { Advice } \\
\text { political cycle, } \\
\text { Monitoring } \\
\text { (control) }\end{array}$ & $\begin{array}{l}\text { Economic loans and cash } \\
\text { transfers, Political process } \\
\text { and bargaining with firms }\end{array}$ & $\begin{array}{l}\text { Information on the } \\
\text { beneficiaries and overall } \\
\text { range, } \\
\text { Information on impact and } \\
\text { social/environmental welfare }\end{array}$ \\
\hline $\begin{array}{l}\text { Market } \\
\text { Actors }\end{array}$ & $\begin{array}{l}\text { Firms (suppliers) } \\
\text { Services Providers } \\
\text { (certifiers, auditing } \\
\text { parties) } \\
\text { Manufacturers }\end{array}$ & $\begin{array}{l}\text { Logistic efficiency, } \\
\text { Material pay-offs }\end{array}$ & $\begin{array}{l}\text { Performance with private } \\
\text { expertise, } \\
\text { Complex network of } \\
\text { deliverables with certification } \\
\text { and auditing procedures }\end{array}$ & $\begin{array}{l}\text { Access and Benefit Sharing } \\
\text { with communities, } \\
\text { Information on revenues and } \\
\text { market }\end{array}$ \\
\hline Social Actors & $\begin{array}{l}\text { Cooperatives } \\
\text { Producers } \\
\text { association } \\
\text { Trade unions (rural } \\
\text { workers) }\end{array}$ & $\begin{array}{l}\text { Traceability, } \\
\text { Increase } \\
\text { membership and } \\
\text { revenue }\end{array}$ & $\begin{array}{l}\text { Collective action with private } \\
\text { incentives }\end{array}$ & $\begin{array}{lr}\text { Information } & \text { about } \\
\text { marginal } & \text { pay-offs } \\
\text { membership } & \end{array}$ \\
\hline
\end{tabular}


The creation of the Convention on Biological Diversity (CBD)and the Cartagena and Nagoya Protocols were based on alarming scientific information provided by epistemic communities on the need to promote sustainable use of natural resources given their limited availability and relation to local social groups in order to avoid the 'tragedy of the commons' (Hardin, 1968), the Nagoya Protocol was introduced in 2010as an addendum to the CBD in an attempt to create a legal framework for both providers and users of the genetic resources, namely, local communities and private actors.In this sense, it recognizes traditional knowledge as a vital part of the regulation as it considers the social and environmental impacts for communities.

Inserted in this context, but operating directly in a transnational arena, the Union for Ethical Bio Trade (UEBT), a non-profit organization, was created in 2007 as part of the United Nations strategy (UN). A former UN official left diplomacy to found this NGO aimed to engage business for ethical biotrade and developed standards for the use of biodiversity based on the principles from the CBD and the Nagoya Protocol with a number of rules and regulations governing the relationship of the signatory companies (biodiversity users) with local communities (biodiversity providers). The NGO promotes the so-called "sourcing with respect" of biodiversity inputs.

Multinationals and suppliers voluntarily comply with the standards and internalize the rule-making in actions, programs and corporate policies. UEBT members adopt 'best practices' stimulating local development and biodiversity conservation. In conclusion, private sector complied with the principles, criteria and UEBT indicators, especially companies in the sectors of pharmaceutical, cosmetics and food. The cooperation between the UEBT and multinational companies takes place in the transnational domain.

There is a local extension of the public-private cooperation in the transnational arena. In the domestic field, the Brazilian state provides the public regulation through the Act (MP2.186-16 (2001)), a bureaucratic and nonbusiness friendly set of rules which created the public good through the universalization of benefit sharing from the protection of genetic resources to Brazilians. The regulatory body CGEN (Conselho Gestor do Patrimônio Genético) approves the projects submitted by firms. At the local level, firms as Beraca have to look for the supply of natural resources in order to meet the demandof clients. To achieve that, Beraca foster collective action at local level with cooperatives and producers association of natural resources, mostly vegetal oils, fruits and seeds.

At the local level, it is also possible to identify the role of certifiers and auditing parties such as the Deutsche Gesellschaft für Internationale Zusammenarbeit (GIZ), a German cooperation agency. In the Amazon communities, it acts through local people that are responsible for in loco verification of the impacts of the company's activities on ecosystems, the conditions by which the collection of oleaginous seeds and fruits takes place as well as the organic standards in the collection and storage of the extracted oleaginous resources to meet UEBT's standards. Ecocert, the French certification body is an accredited institution responsible for issuing the certification that ensures that oleaginous seed sand fruits have been collected according to organic standards (collection, storage and processing of seeds and fruits) and that no child or forced labor has been used in the extractive activity.

Similarly, although local institutional arrangements succeed in an effective and legitimate way, setting an extraction limit 'authorized' by families does not 'scale up' because it depends on an authority that can aggregate and systematize the information. This authority is placed in a layer above the local level. It can be composed of a sub-national or national public authority, by an authority built by the market (company or association), the third sector (NGOs) or a combination of both. This authority is a provider of qualified information that 'authorizes' locally the decision taken by governments and formal IOs. However, the source of information is local. Thus, the central issue is to understand the source of local information regarding the 'authorized' levels of extraction of the natural resources.

The local institutional arrangement created for the collection of seeds is stimulated by a network of stakeholders operating in the local communities through local cooperatives. They require a complex institutional design in the form of rules so that the objectives are achieved. The institutional design is the result of the combination of some variables such as the market incentives, the transaction costs, the capabilities (skills) of families with regard to the diversity of income-generating activities and governance structures for the extraction and for other productive activities performed by families that can either be complementary to those existing or can compete with them, affecting the social and environmental impacts. The combination of these variables results in a model for the company's relationship with local communities, and these with the global cosmetics market through a network of stakeholders. 


\subsection{Stakeholder theory and Beraca's leadership}

Beraca's performanceis intimately linked to the Stakeholder Theory that emphasizes the role of actors related to the company's operation. In other words, the company incentives a network of stakeholders vertically and horizontally integrated in a multilevel system that ranges from the international to the local level (Freeman, 1984, 1994, Clarkson, 1995,Donaldson and Preston, 1995). In fact, all the levels are embedded in the transnational arena as shown in the figure below. However, we argue that the company is the only actor that has a stake at all levels, either public or private - that is what we call 'multilevel mobility'. Therefore, Beraca is capable of ensuring that the compliance of the standards that regulate the use of biodiversity occurs at the local communities which are the groups aimed by the Convention on Biological Diversity (CBD) and the Nagoya Protocol (international level) when it comes to Access and Benefit Sharing (ABS) (at national and local levels).

Figure 1: Multilevel mobility

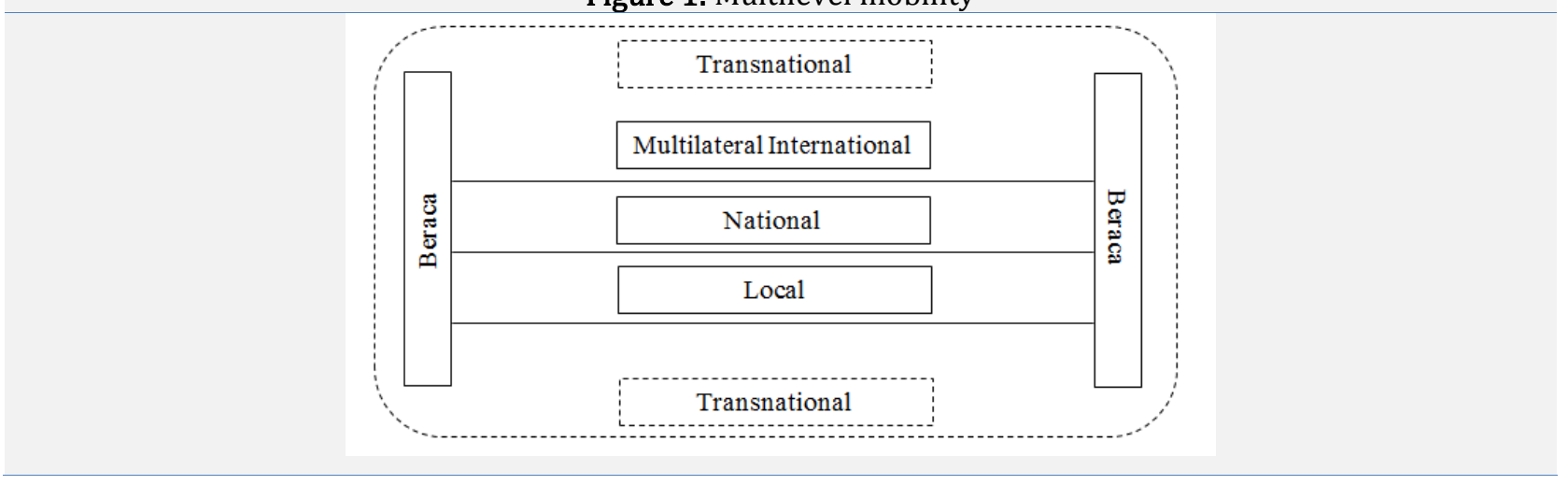

The multilevel mobility is related to the 'authoritative governance' (Cutler, 2003) that operates in-between the levels. This means that the company basically faces two challenges to deal with all the other actors in different arenas simultaneously: 1 . the company can use its multilevel presence to project the corporate strategy at the same time it acts as a local enforcer of public/private standards from States and IOs and from the UEBT and 2. the company seeks legitimacy among States and IOs which are considered the traditional actors in International Relations and Political Science (Mitchel, Agle and Wood, 1997,Frooman, 1999). Legitimacy is reached with the expertise that is developed within the corporate strategy projected to the context in which the company is inserted. It is a chance for the private actor to have a stake at all levels and ensure that legitimacy is gained through 'best practices' given the lack of enforcement mechanisms by the traditional actors. Thus, Beraca influences the enforcement of the public principles that are in the Convention of Biological Diversity and in the Nagoya Protocol whose compliance occurs at the local level in a process that involves the delegation from public actors to the company.

Mitchel et al (1997, p. 897) developed a diagram which illustrates the network of stakeholders and the central role of a company given their attributes - power, legitimacy and urgency - and their capacity to exert influence on the issue-area to which they are related. When it comes to biodiversity, we have a fourth attribute: mobility. This attribute is a characteristic of companies that have a stake at all levels of analysis as discussed previously. We believe that understanding mobility along with the other attributes and the actors' capacity to influence the environmental agenda helps to clarify what 'authoritative governance' (Cutler, 2003) is all about.

Figure 2: Typolgy of stakeholders in biodiversity regulation

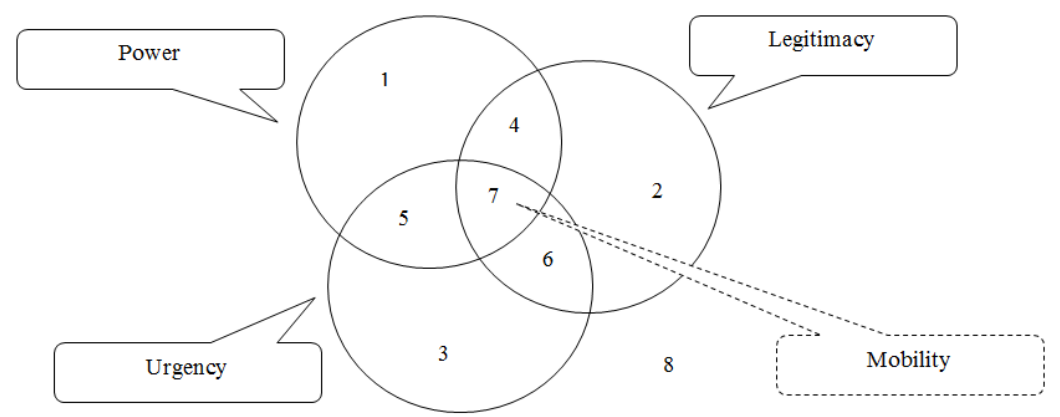

Source:Mitchel et al (1997, p. 897), adapted by the authors. 
The typology was created to explain the corporate endogenous environment and how stakeholders influence the organization of a company itself. However, we externalize the same model to link the stakeholder theory to therole played by Beraca in the multilevel context that involves the biodiversity agenda in transnational arenas. Given this, it is possible to identify the stakeholders that are numbered from 1 to 8 given their attributes.

Stakeholders 1, 2 and 3 are considered those with low capacity to influence the process as they delegate roles to non-state actors. In this domain, it is possible to place States and IOs as they do not have efficient mechanisms to regulate the use of biodiversity. Despite the (weak) public regulation at the national level, the Brazilian biodiversity is mainly regulated by non-state actors such as companies and NGOs through public/private standards along with public regulatory bodies such as CGEN. Companies and NGOs have two attributes that are vital for their role: influence and increasing legitimacy. 4, 5 and 6 are the stakeholders with high influence and urgency on the whole process. This is where NGOs, activists and the local communities are placed. They are part of the participatory character which is a principle in the CDB and in the Nagoya Protocol.

We argue that biodiversity regulation has a bottom-up approach given that local communities are the target groups contemplated by the international public regulation as the traditional knowledge is a valuable asset to biodiversity sustainable use and conservation. Stakeholder 7 is the private actor. Beraca has all the four attributes (legitimacy, power, urgency and mobility). In this context, power is defined as the ability to influence an agenda. This is justified by the commitments that Beraca has managed to fulfill.

Finally, the Stakeholder Theory has three main natures: 1. descriptive/empirical: this is related to the corporate governance. 2. Instrumental: it is related to the promotion of profitable and productive activities and 3. normative: it is how the descriptive and the instrumental nature is translated into practices that affect other dimensions related to the context in which the company operates (Barbieri and Cajazeira, 2015). This is clear in the case of the UEBT that promotes principles and practices that both expand the company's business and promotes the sustainable use of biodiversity.

\subsection{National public regulation and market incentives}

The Brazilian institutional environment has never been favorable to the commercial use of the Brazilian biodiversity. The regulation and the regulatory body were created as a reaction to a case of biopiracy involving a Swiss multinational pharmaceutical company. The Brazilian government created a 'bureaucratic monster' which practically prevented the development of research with natural inputs in Brazil until 2015, when a more 'business friendly' bill was approved and sanctioned by the president (LeiNo 13.123, 20th of May, 2015). The government's objective was to prevent multinational companies, organizations and individuals, inspired by the traditional knowledge and motivated by economic interests, from stealing molecules of the Brazilian fauna and florato turn them into pharmaceutical products and cosmetics abroad (Barreto, 2012).

MedidaProvisória (MP) 2.186-16 (2001) established the regulatory framework for access and protection of genetic resources, and the sharing of fair and equitable benefits, as suggested by the Convention on Biological Diversity (CBB) in the articles 10 and 15 and in the Nagoya Protocol in the articles 5, 6, 7 and 12. The MP defined the concept of genetic resources and traditional knowledge of both local communities and indigenous groups. Through this measure, the Brazilian government created the regulatory body to protect the Brazilian genetic heritage (CGEN) under the Ministry of the Environment.

The creation of the Brazilian regulatory framework in 2001 would have been a reaction to a case of biopiracy. In 2000, a non-profit entity that received money for research from the Brazilian government money, BioAmazônia, would have negotiated with the Swiss multinational Novartis the right to use the genetic material from the forest without government authorization. The contract between Bio Amazônia and Novartis was to send strains of bacteria to the Swiss company to be used in the research of potential medicines. The compounds would be jointly owned by the two parties, but Novartis would have perpetual and exclusive rights along with the possibility of licensing to third parties to manufacture, use and sell any products containing the original or the derived compound. This case was interpreted by the Brazilian authorities and environmentalist NGOs as a case of biopiracy, which have encouraged the creation of a highly interventionist and punitive regulation to make the use of biodiversity not viable for commercial purposes (Danley, 2011,Scott, 2003).

Firstly, MP 2.186-16 (2001) created an institutional system where every product that was released with natural raw materials from the Brazilian biodiversity must go through a proceeding to be approved by a council composed of various ministries and government institutions - 19 bodies and entities of the Federal Public Administration with voting rights. This is a way to hinder the decision-making process and to discourage research initiatives and development of new inputs from the private sector. Companies depended on rapid 
approval of projects for the inputs to compose new lines of cosmetics that brought product and/or process innovation(CNI,2012).

The difficulty to process rapid decisions produced a strong legal uncertainty, making many companies to give up searching and use Brazilian biodiversity in processes and technological products. Moreover, some concepts of the MP helped to create this legal uncertainty for the private sector, such as the genetic heritage related to the landowner and not a right of the whole population.Secondly, it emphasizes the highly monitoring and penalty character of the MPwith the application of heavy finesand penalties on companies, universities and research centers.

In 2010, the InstitutoBrasileiro do MeioAmbiente e dos Recursos Naturais Renováveis (IBAMA) triggered the operation called Novos Rumos, notifying Research Institutions, companies of the pharmaceutical, cosmetic and agriculture sectors accused of biopiracy and investigated by the alleged illegal collection of the Brazilian biodiversity products. The action of the government virtually placed all private companies in an illegal situation in relation to the procedures of submission, approval and development of natural inputs for commercial purposes.

The failure of the Brazilian public regulation to ensure balanced access to genetic resources highlights the competitive strategy of Beraca. The three action axis (preservation of biodiversity, respect for labor standards and access to water resources) projected the company as a supplier of natural raw materials among the large multinational companies in the cosmetics, food and pharmaceutical sectors.

With the global market incentives, Beraca has strengthened its operations in research and development of natural biodiversity resources. With the bill passed in 2015, this strategy will consolidate and Brazil will start to project a soft power anchored in expertise and know-how in how to deliver natural inputs from a complex local institutional arrangement, based on strong partnerships with communities and local NGOs.

\subsection{Conclusions}

Globalization has favored the establishment of transnational arenas, with diffuse authority and enforcement promoted by cooperation between companies, governments and the third sector. In the present case, it was found that a company operating in sector of natural raw materials, Beraca, and an NGO called UEBT 'interpret' and 'enforce' the regulation regarding the biodiversity protection and ABS.

To implement the regulation, a functional institutional arrangement must be created at the local level and the driver would be the reduction of transaction costs. Encourage families to collective action, create cooperatives through market incentives, promote the welfare and environmental protection, certify and ensure the quality standards of the fruits and seeds are the duties with which Beraca share with a large number of actors atthe local level. It was all achieved in a non-friendly atmosphere with the Brazilian government that was not favorable.

It's hard to explain the success of Beraca without mentioning the transnational connection. Most companies in Brazil discontinued Research \& Development (R\&D) projects in products and processes for the commercial use of biodiversity. Due to the negative incentives of the Brazilian regulatory framework, Beraca would have done the same as its competitors. However, expertise to develop sustainable chains, and the know-how acquired in the delivery of natural inputs has projected the company among the large global players. How did this happen and what are the implications in terms of policy?

The table below seeks to reveal the chain of levels of analysis suggested in the article. For this reason, we identify at each level which is the authority that formally or informally 'authorizes' the lower level and triggers the implementation of the agreement on the rules and regulations. It starts in arenas and then the authority and the process of implementation are identified. The assumption is that multilevel global governance reaches the local/regional dimension so that users are 'authorized' to use the natural resource as shown in table 3.

Table 3: Arenas and authority in global environmental governance

\begin{tabular}{ll}
\multicolumn{2}{c}{ Table 3: Arenas and authority in global environmental governance } \\
Arenas & Who 'Authorizes'? \\
\hline Multilateral Intergovernmental & Treaties, Conventions and Protocols \\
Transnational & NGOs, Multi stake holder Initiatives, Corporate 'Best \\
National & Practices', Transnational Institutional Arrangements \\
Subnational & Public Regulation \\
Local & Public Regulation \\
& Communities of Users
\end{tabular}


In this sense, verifying the implementation of the rule at the local level is one way to validate and legitimize international agreements and the decision-making process that originated them. At the same time, it allows to check how individuals are important agents to increase the effectiveness of international agreements that supposedly promote the sustainable use of natural resources as well as non-state actors that are inserted within the local context, such as NGOs and the private sector and how they are the protagonists in issues that mix public and private arenas (Ruggie, 2004).

The multilevel environmental governance demands instruments and 'authoritative' mechanisms that are recognized in the dynamics of 'scaling down' of multilateral environmental agreements. The academic literature of international regimes and global governance was concerned to explain the horizontal cooperation between states, the lack of enforcement and the decision-making process and how effective and legitimate it may be. However, more operational elements of the implementation of the agreements were left aside as it was understood that sovereign states held the institutional tools to do so. However, on environmental issues it is clear that this does not happen.

As in many of the international environmental regimes there is no direct correspondence between the multilateral intergovernmental decision-making process and the formal instruments of enforcement (contemplated in the Convention and in the Protocol) and compliance by the parties, the implementation of the agreed rules shifts to transnational arenas occupied by non-state actors (NGOs and businesses) described above.

\section{References}

Abbott KW, Snidal D (2010). International regulation without international government: improving IO performance through orchestration. The Review of International Organizations, v. 5, n. 3, p. 315344.http://dx.doi.org/10.1007/s11558-010-9092-3

AbramovayR, Magalhães R, Schroder M (2010). Representatividade e inovação na governança dos processos participativos: o caso das organizações brasileiras de agricultores familiares.

Auld G (2014). Constructing Private Governance: The Rise and Evolution of Forest, Coffee, and Fisheries Certification. Yale University Press.http://dx.doi.org/10.12987/yale/9780300190533.001.0001

Barbieri JC, Cajazeira JER (2015). Responsabilidade Social Empresarial e Empresa Sustentável - da Teoria À Prática. 2 ${ }^{\mathrm{a}}$ Ed. EditoraSaraiva.

Barreto DW (2012). Patrimônio genético brasileiro: protegê-lo ou aproveitá-lo comercialmente?.Journal of the Brazilian Chemical Society, v. 23, n. 2, p. 191-193.http://dx.doi.org/10.1590/s0103-50532012000200001

Bartley T (2007). Institutional Emergence in an Era of Globalization: The Rise of Transnational Private Regulation of Labor and Environmental Conditions1. American Journal of Sociology, v. 113, n. 2, p. 297351.http://dx.doi.org/10.1086/518871

Bernstein S (2011). Legitimacy in intergovernmental and non-state global governance. Review of International Political Economy, v. 18, n. 1, p. 17-51.http://dx.doi.org/10.1080/09692290903173087

Börzel TA, Risse T (2010). Governance without a state: Can it work? Regulation \& Governance, v. 4, n. 2, p. 113134.http://dx.doi.org/10.1111/j.1748-5991.2010.01076.x

BütheT (2010). Private regulation in the global economy: a (P) review. Business and Politics, v. 12 , n. 3. http://dx.doi.org/10.2202/1469-3569.1328, http://dx.doi.org/10.2202/1469-3569.1349

Büthe T, Mattli W (2011). The new global rulers. The Privatization of Regulation in the World Economy, Princeton. http://dx.doi.org/10.1515/9781400838790

Cashore B (2002). Legitimacy and the privatization of environmental governance: how non-state market-driven (NSMD) governance systems gain rule-making authority. Governance, v. 15, n. 4, p. 503529.http://dx.doi.org/10.1111/1468-0491.00199

ClarksonME (1995). A stakeholder framework for analyzing and evaluating corporate social performance. Academy of management review, v. 20, n. 1, p. 92-117, 1995.http://dx.doi.org/10.2307/258888

Coase RH (2012). The nature of the firm. Economica, v. 4, n. 16, p. 386-405, 1937.http://dx.doi.org/10.1007/978-3-642-27922-5_22

Confederação Nacional da Indústria (CNI). Biodiversidade e Indústria - Informações para uma Gestão Sustentável, Brasília, 149 p.

Cutler AC (2003). Private power and global authority: transnational merchant law in the global political economy. Cambridge University Press. http://dx.doi.org/10.1017/cbo9780511550300

Danley V (2011). Biopiracy in the Brazilian Amazon: Learning from International and Comparative Law Successes and Shortcomings to Help Promote Biodiversity Conservation in Brazil. Fla. A \& M UL Rev., v. 7, p. 291.

Donaldson T, Preston LE (1995). The stakeholder theory of the corporation: Concepts, evidence, and implications. Academy of management Review, v. 20, n. 1, p. 65-91.http://dx.doi.org/10.2307/258887

Freeman R (1984). Strategic management: a stakeholder approach. Boston: Pitman, 276p. 
FroomanJ (1999). Stakeholder influence strategies. Academy of management review, v. 24, n. 2, p. 191-205. http://dx.doi.org/10.5465/AMR.1999.1893928, http://dx.doi.org/10.2307/259074

Green JF (2010). Private standards in the climate regime: the greenhouse gas protocol. Business and Politics, v. 12, n. 3.http://dx.doi.org/10.2202/1469-3569.1318

Hale T, Held D (2011). Handbook of Transnational Governance. Polity.

Hall RB, Biersteker TJ (2002). The emergence of private authority in global governance. Cambridge University Press.http://dx.doi.org/10.1017/CB09780511491238

Hardin, G (1968). The tragedy of the commons. Science, v. 162, n. 3859, p. 12431248.http://dx.doi.org/10.1126/science.162.3859.1243

Katsikas D (2010). Non-state authority and global governance. Review of International Studies, v. 36, n. S1, p. 113-135.http://dx.doi.org/10.1017/s0260210510000793

Keohane RO (1984). After hegemony: Cooperation and discord in the world political economy. Princeton University Press.

Keohane RO, Ostrom E (1995). Local commons and global interdependence: heterogeneity and cooperation in two domains. London: Sage.

Link AN, Link JR (2009). Government as Entrepreneur, New York, Oxford University Press.http://dx.doi.org/10.1093/acprof:oso/9780195369458.001.0001

Mattews RCO (1986). The economics of Institutions and the Sources of Economic Growth. EconomicJournal, v. 96, n. 4, p. 903-18.http://dx.doi.org/10.2307/2233164

Medida Provisória 2186-16 (2001). Regulamenta o acesso ao patrimônio genético e a repartição de benefícios (www.planalto.gov.br. Access: 27th of July, 2015.).

Mitchell RK, Agle BR, Wood DJ (1997). Toward a theory of stakeholder identification and salience: Defining the principle of who and what really counts. Academy of management review, v. 22, n. 4, p. 853886.http://dx.doi.org/10.5465/AMR.1997.9711022105

North DC (1990). Institutions, institutional change and economic performance. Cambridge University Press.http://dx.doi.org/10.1017/cbo9780511808678

North DC (1991). Institutions. Journal of Economic Perspectives, v. 5, n. 1 , p. 97 112.http://dx.doi.org/10.1257/jep.5.1.97

Pattberg PH (2007). Private institutions and global governance: the new politics of environmental sustainability. Edward Elgar Pub.

RaynoldsLT (2009). Mainstreaming Fair Trade Coffee: from partnership to traceability. World Development, v. 37, n. 6, p. 1083-1093.http://dx.doi.org/10.1016/j.worlddev.2008.10.001

Ruggie JG (2004). Reconstituting the global public domain - issues, actors, and practices. European Journal of International Relations, v. 10, n. 4, p. 499-531.http://dx.doi.org/10.1177/1354066104047847

Scott RL (2003). Bio-Conservation or Bio-Exploitation: An Analysis of the Active Ingredients Discovery Agreement between the Brazilian Institution Bioamazonia and the Swiss Pharmaceutical Company Novarts. Geo. Wash. Int'l L. Rev., v. 35, p. 977.

Williamson OE (2000). The new institutional economics: taking stock, looking ahead. Journal of economic literature, p. 595-613.http://dx.doi.org/10.1257/jel.38.3.595

Williamson OE (1996). The mechanisms of governance. Oxford University Press.

Young OR (2011). Effectiveness of international environmental regimes: Existing knowledge, cutting-edge themes, and research strategies. Proceedings of the National Academy of Sciences, v. 108, n. 50, p. 1985319860.http://dx.doi.org/10.1073/pnas.1111690108

Young 0 (1999). "Is Enforcement the Achilles' Heel of International Regimes?" In: YOUNG, Oran R. Governance in world affairs. Cornell University Press. 